\title{
Innovation as a Determinant Facing the Covid-19 Pandemic (Qualitative Study on "Beckrem - Bebek Rempah Semarangan”)
}

\author{
1. Adi Ekopriyono \\ University of 17 August 1945 \\ Faculty of Economics and Business, \\ Semarang City \\ Indonesia \\ adieko.bsf@gmail.com
}

\author{
2. Natalia Sari Pujiastuti \\ University of Semarang (USM) \\ Faculty of Information \& \\ Communication Technology \\ Semarang City \\ Indonesia \\ naneth.ekopriyono2@gmail.com
}

\author{
3. Banu Prasetyo \\ Institute 10 November Surabaya (ITS) \\ Faculty of Creative Design \\ and Digital Business \\ Surabaya City \\ Indonesia \\ bp.signora@gmail.com
}

\begin{abstract}
During the Covid-19 pandemic, many enterprises made innovations to attract consumers and increase competitiveness to maintain their businesses. "Beckrem - Bebek Rempah Semarangan" is one of the enterprises that innovate as a survival strategy. This qualitative study reveals the strategy's dimensions of direct observation, focus group discussion, and in-depth interviews with the culinary business actors. This study shows that innovation is a determining factor for enterprises to survive during the Covid-19 pandemic. They must make renovations before launching innovation, implementing comprehensive product and service innovations, making innovations based on consumer wants and needs, and online marketing.
\end{abstract}

Keywords: Innovation, enterprise, product, service

\section{INTRODUCTION}

Globalization and rapid technological changes have shifted the current pattern of business competition [1]. Entrepreneurs must continue to improve knowledge and new technology to ensure long-term survival [2]. Innovation is necessary to gain a favorable position at the local or national level and in the global economy. Competitiveness is a general requirement for entrepreneurs who wish to develop.

The term innovation was first used by Schumpeter, who considered innovation to be the engine of the market economy. Entrepreneurs who decide to innovate have a high chance of making a profit. Innovation is the destructive power of creativity. In this process, entrepreneurs play a crucial role because they are missionaries of progress [3].

Innovation is a unique tool for entrepreneurs; a change creates opportunities to open new businesses or provide new products and services. Innovation can be considered as a scientific discipline. It can also be learning and practice. Entrepreneurs must look for changes and symptoms that point to opportunities for practical innovation. The innovation process is a structured, systematic, and purposeful procedure based on transparent principles of action, enabling entrepreneurs to turn ideas into concrete innovations [4]

According to $\mathrm{Ch}$. Freeman [5], not innovating means dying. Innovation is any change, which first becomes a meaningful trade subject. Jack Trout in Differentiate or Die:
Survival in Our Era of Killer Competition [6] writes, products must be different from competing products, based on four ways, namely quality and consumer orientation, creativity, price, and the breadth of product choices.

Kuznets [7] emphasized that innovation is the first or reuse of old or new knowledge in the production process, system, or devices. The only thing constant in modern economies is change. Innovation is a guarantee for success and survival, regardless of the size and field of industry in which it operates.

Innovation is essential in the maintenance and growth of companies and emerging entities [8]. According to Kotler [9], business actors must develop many new products to be successful. Product innovation is focused primarily on market needs, and process innovation aims to increase the production process's efficiency [10].

In a general sense, organizational innovation relates to creating, introducing, or adapting new ideas or behaviors in organizations [11]. Innovations are new or significantly improved products and services that have been commercialized or new or revised considerably processes used for the commercial production of goods and services [12].

Based on these descriptions, it can be concluded that innovation is an update in products and services that produces added value for consumers, thereby increasing enterprise turnover. Innovations that have no commercial value are not promising.

This study chose Beckrem-Bebek Rempah Semarangan (from now on referred to as Beckrem) as the research object. It is one of the small enterprise culinary in Semarang City, established on January 1, 2015. At the pandemic time, Beckrem was trying to survive in running the business activities, despite facing difficulties, mostly due to the drastic decline in turnover.

The research object's selection is based on the following arguments: (1) This culinary business managed to survive for about six years, precisely when many similar businesses closed. Now, Beckrem has three outlets, namely at Kapas Raya Street F 763 Genuk Indah, DP Mall Food Court, and Ciputra Mall Food Fair; all in the Semarang City; (2) This culinary business is trying to implement an innovation strategy 
as an effort to survive during a pandemic. (3) The authors are shareholders in this business, so they understand the business development.

\section{METHODOLOGY}

\section{A. Research Design}

This study uses a qualitative research method, beginning with a theoretical dimension as a reference for field research in a period of nine months, January to September 2020. Empirical findings are used to formulate new thinking. The flow of this research starts from describing the business phenomenon, literature review, and then formulating the problem, the data collection, data analysis, and interpretation of research analysis. Then, followed by compiled report research.

This study aims to determine the effective ways to innovate to increase turnover during the pandemic.

The design can be described as follows:

\section{Research Design}

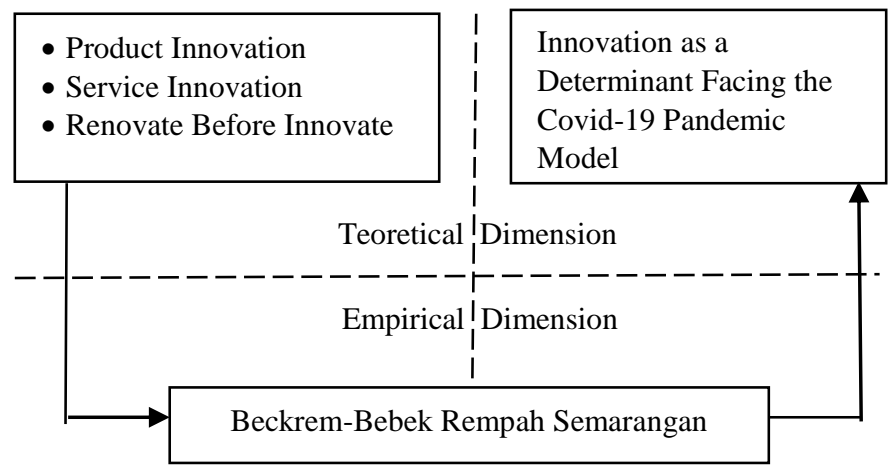

\section{B. Research Question}

During the Covid-19 pandemic, innovation is the keyword for entrepreneurs in overcoming the turnover decline caused by various community activities restrictions. The question is, what kind of innovation model is useful for increasing turnover. Research questions in this study are: (1) How is product innovation effective in improving turnover? (2) How are service innovations that are effective in increasing turnover? (3) Are there other factors that drive innovation?

\section{Data Collection}

Primary data collection in this study was carried out through direct observation, focus group discussion (FGD) that are conducted every three months, and in-depth interviews with Beckrem employees s informants, namely: Siti Kaisah as a product manager, Sarwoto (chef), Markamah (general staff), Safa (production staff), Hidayah (production staff), Nurnina, Azis, and Erny as outlet persons. Secondary data were obtained from Beckrem documents.

\section{Limitation and suggestion for future study}

This study's limitation is that it only examines two dimensions of innovation: product innovation and service innovation. There are still other dimensions, for example, related to process and technology. Therefore, this study can be followed up by further research that comprehensively examines the dimensions of innovation.

\section{E. Our Contribution}

This study explains the importance of product innovation and service innovation for entrepreneurs to increase turnover during the Covid-19 pandemic. This study's findings are expected to successfully provide input for entrepreneurs to overcome the difficulties caused by the Covid-19 pandemic.

\section{CONCEPTUAL BACKGROUND}

\section{A. Product Innovation Dimensions}

A new product's commercial success depends on how well the product design meets customer needs [13 \& 14]. According to Kotler and Armstrong [15], product innovation has three indicators: product quality, product variants, product style, and design.

- Product quality: the ability of a product to perform its functions, including durability, reliability, and accuracy.

- Product variant: a competitive means of differentiating one product from another or between products owned by competitors' products.

- Product style and design: which is another way of adding value to customers. Style only describes a particular product's appearance, whereas design has a concept that is more than a style.

Product innovation requires collective action or efforts to create shared understandings from disparate perspectives. The advocation of analytical tools and processes, the infusion of market research information, and the redesign of structures, while important, are not enough.

Deborah et al. research [16] seeks to explain why innovators fail to develop a comprehensive appreciation of the product in its market. Three implications are developed from the findings. First, collaboration is necessary to technologymarket linking, which means that collaboration enhances the product's design and improves the execution of the development process. Second, the styles in which people organize their thinking and action about innovation-their "interpretive schemes"-are significant barriers to linking and collaboration.

\section{B. Service Innovation Dimensions}

The service innovation dimension is measured by the extent to which there are updates in service quality, as stated by Zeithaml [17], namely:

- Reliability: the ability to deliver services sincerely.

- Responsiveness: willingness to help service users and provide services sincerely.

- Assurance or certainty: knowledge, politeness, and ability of service providers in giving trust to service users.

- Empathy: the ability to pay attention to individual service users.

Innovation is a significant determinant for service excellence. To provide innovative services is needed to be 
reliable, provide flexible products, and continually update their products. However, this should be combined with other antecedents, including appropriate rates, technological advancements, reputation, and excellent employees. Practical implications include considering innovation [18].

Hanif and Asgher [19] offer new insights into service innovation management and performance management. The multi-dimensional nature of service innovation is highlighted in two stages. The former stage throws light on the relationship between the main variables of service innovation, service innovation performance, and business environment.

The latter explores these variables further by examining and validating inter-dimensional relationships between the variables. The study finds that service innovation significantly impacts performance. This finding is in line with the many studies carried out on service innovation concerning service innovation performance. It reinforces the previous findings that service innovation directly and significantly impacts service innovation performance.

The business environment role in terms of dynamism and competitiveness was tested, hypothesized to interact between service innovation and performance. The business environment has shown in the previous research to interact between innovation and performance.

\section{RESULT AND DISCUSSION}

\section{A. Renovation Before Innovation}

From direct observations, focus group discussions, and indepth interviews, there is an exciting finding that all informants mentioned that the most crucial step in making innovation, both products and services, is renovation first. These findings support Sergio Zyman's thesis [20]. Innovation is essential for business growth, but the risks are far more significant than the results obtained. There is another way to advance the company, namely the renovation strategy. Companies do not need to make significant changes but do something better with the assets and competencies.

In Zyman perspective, entrepreneurs must review and revise the six components of the business, namely: (1) the way of thinking: think like a challenger, not as a champion; (2) the ultimate goal: set back the goals and hopes for the company in the decades to come; (3) the framework of the competition or competitiveness: the factors that make competing with competitors, maybe something is not needed, or otherwise, something is needed but not done; (4) segmentation: the initial plan or program when the product is launched may change because customers and product users are different from what the original thought; (5) brand positioning: brand positioning needs to be reviewed, especially with counter-attacks from competitors, it could be that the brand positioning is not sharp, deviating from the goal; (6) the consumer's experience: the consumer experience is an essential input or feedback to determine, both positioning and segmentation in the future.

With a different emphasis, Stephen Brown [21] writes, there is another intriguing option: Renovate. As the recent rapid rise of retro branding bears witness, renovation is all the rage. Innovation is one of many magic words in contemporary management discourse. Nevertheless, for all the talk of the next level, genuine innovations are comparatively rare. Just as scientific paradigm shifts are few and far between, "really new products" are like lottery wins, more aspired to than attained. Although renovation lacks the allure of its lauded antithesis, the metaphorical and mysterious machinery of renovation represents a possible new frontier for marketing scholarship.

Regardless of the in-depth interview answer, the informants can be divided into two groups: the production group responsible for preparing products and the sales group in charge of selling products at outlets.

All production personnel agrees that renovating the way of thinking is an essential factor before making innovation, related to employee demotivation symptoms during the pandemic. Demotivation occurs, among others, due to stagnant turnover and boredom in dealing with less enthusiastic conditions.

It is as if they are trapped in a comfort zone condition, so they do not need achievement (N-Ach). Demotivation is also affected by reduced income and does not get overtime pay because turnover is only around 30 percent compared to the period before the pandemic.

According to them, the other five Zyman renovation components [20] are good enough. Siti emphasized that the problem that must be addressed before making innovation is employees' way of thinking, from a winner's mindset to a challenger. Thus, discipline and enthusiasm for doing their best will increase too.

Meanwhile, the sales group argues that the urgent thing to do is to expand the segmentation. So far, most of Beckrem's consumers are middle-up because the product's price is relatively high. During this pandemic, it is necessary to apply more affordable prices to attract more consumers. Nurnina explained that there are often potential buyers who give up after seeing the menu's price list.

Even though they agree that renovation is essential, the two groups of employees still need innovation strategies, product innovation, and service innovation. Renovations and innovations can be implemented together so that turnover will return to normal or even increase during the Covid-19 pandemic.

In other words, fostering an innovation orientation requires the employees' entrepreneurial spirit. They must have a strong entrepreneurial orientation so that they are passionate about innovating to sustain their business. The higher the entrepreneurial orientation, the higher the innovation orientation. This finding is consistent with Darmanto's [22] research that entrepreneurial orientation positively and significantly affects innovation orientation.

\section{B. Product Innovation}

As already described, there are three indicators of product innovation, namely quality, variant, style, and design [15]. All employees believe that Beckrem's products are adequate in terms of quality because they have been tested many times during their six years of operation. However, there is an 
exciting finding, which is related to hygiene. Sarwoto emphasized that the hygiene factor needs to be added as an indicator of product innovation during the Covid-19 pandemic.

His reason is that many consumers are sensitive to hygiene factors. Consumer positive perceptions of this factor will significantly influence purchasing decisions. Therefore, product innovation must include updates in the production process following the CHSE protocol (Cleanliness, Hygiene, Safety, and Environmental sustainability).

According to Siti, Beckrem anticipates hygiene issues by following the CHSE certification, thereby convincing consumers that the production process follows the CHSE principles. This certification also increases employees' confidence in promoting products.

Besides, Beckrem also has a halal certificate from the Indonesian Ulema Council (Majelis Ulama Indonesia - MUI). This certificate, according to Siti, is essential, especially for Muslim consumers. He met consumers several times, especially from offices, families, and specific communities, who asked whether Beckrem's products had been certified halal. She is also sure, with the certificate obtained, consumer confidence will increase, thereby increasing turnover.

Product quality, according to the employees, is a critical factor in product innovation. The product's perceived quality will determine the extent of the consumer's emotional attachment to the product. Therefore, the essence of the steps to make product innovation is to maintain and develop quality.

Regarding product variants, four employees rated this indicator as affecting increasing sales. According to them, new products and new menus have succeeded in attracting new customers and consumers. The other four employees thought that product variants did not affect because most Beckrem consumers were loyal customers who already had their favorite menu choices.

All employees stated that product style and design affected increasing turnover, as it was proven that Beckrem's style and design innovations during the pandemic had succeeded in attracting consumers. Markamah and Erni cite the importance of style and design as a reflection that Beckrem's consumers "fall in love at first sight."

\section{Service Innovation}

As already described, service innovation can be assessed from four dimensions, namely reliability, responsiveness, assurance or certainty, and empathy [17]. All employees stated that all dimensions of service innovation are critical to increasing turnover.

The four dimensions are interconnected, must be carried out simultaneously because the essence lies in the mindset. This opinion is in line with the view of the importance of renovation before innovation. In several FGDs, it was revealed that in addition to renewing the mindset of winners becoming challengers, it also needs to become a serving mindset. The ability to provide services in a manner that fosters trust, courtesy and empathy for consumers must be the obligation of employees. If this can be done, it will affect consumer interest, which in turn will increase turnover.
The essence of the four dimensions of service innovation is service quality. Good service quality will result in customer satisfaction. Consumer satisfaction will result in repeat purchases and positive customer-to-consumer stories or what is often referred to as word of mouth (WoM) marketing, which increases sales. Therefore, service innovations that improve service quality will increase re-purchases and turnover. These findings are sustainable with Ela Zakiya Muslichati and Sri Wartini's research results [23].

Several FGDs and in-depth interviews also found another dimension, namely online services within the online marketing framework. This dimension is very decisive during a pandemic because many people are lazy to travel due to the activity restrictions policy.

All employees also think that entering online marketing is not as easy as imagined because nowadays, almost all entrepreneurs launch online marketing. As a result, competition is very fierce, so they have to more creative. The more creativity, the more guaranteed the success of service innovation by implementing online marketing.

Sarwoto says online marketing must be carried out selectively and indeed, according to consumer want and need. He agrees that online services or online marketing are very significant to increase customer satisfaction and ultimately increase turnover.

Beckrem took steps to innovate online services, updating the promotional design to be uploaded on social media: Facebook, Instagram, and WhatsApp. The next step is to collaborate with online payment providers: gopay, grab pay, OVO, banking edition (Bank BCA and Bank Mandiri). At the same time, this culinary business has also entered the Tokopedia marketplace and applies postage discounts.

These steps, according to Sarwoto, are quite successful in bringing the product closer to consumers. The number of customers turning online is increasing day by day. The increase is not only in individual consumers but also in offices. Product orders for meeting consumption, family gatherings have also increased.

The following is Beckrem's turnover data for January to September 2020:

January-September 2020 Turnover Data

\begin{tabular}{|l|r|}
\hline \multicolumn{1}{|c|}{ Month } & Turnover \\
\hline January & 96.269 .291 \\
\hline February & 92.044 .045 \\
\hline March & 53.850 .251 \\
\hline April & 15.692 .090 \\
\hline May & 33.797 .596 \\
\hline June & 29.690 .969 \\
\hline July & 26.744 .792 \\
\hline August & 44.038 .886 \\
\hline September & 36.183 .855 \\
\hline
\end{tabular}

The data shows that the Beckrem turnover before the Covid-19 pandemic (January-February 2020) reached IDR 90 million per month. During the pandemic (March-September 2020) dropped drastically to IDR 132.456.306 on average. Nevertheless, there is an increasing trend in August (IDR $44,038,886$ ) and September (IDR 36,183,855). This increase is in parallel with the online service innovation efforts being 
made. According to Siti, the increase was mainly due to increased online orders, both through online orders and emoney payment. The increase in online sales ranged from $20 \%$ to $30 \%$.

\section{CONCLUSION}

Based on the results and discussions, it can be concluded as follows:

1. Innovation is a determining factor for entrepreneurs in facing the Covid-19 pandemic, significantly increasing turnover to survive. However, innovation alone is not enough because renovations must support it by optimizing existing resources, significantly changing the employee's way of thinking from a winner to a challenger and being more disciplined and enthusiastic. These findings show that renovations are significant to do to overcome employee demotivation during the Covid-19 pandemic. Renovations also need to be done to expand segmentation to reach more consumers. One way is to hope for a more affordable pricing strategy as consumer purchasing power declines during a pandemic. Besides, it is no less essential to encourage employees to have an entrepreneurial spirit. They must have a strong entrepreneurial orientation so that they are passionate about innovating to sustain their business.

2. Product innovation is an essential dimension in facing difficult conditions during the Covid-19 pandemic. Product innovation must be carried out, but prioritizing hygiene factors to anticipate consumer sensitivity. These findings indicate that during the Covid-19 pandemic, hygiene was a significant factor and determines purchasing decisions. The more product is perceived as clean and healthy, the more desirable it will be for consumers. Therefore, hygiene needs to be included in product innovation indicators in any research related to how entrepreneurs overcome difficulties during the Covid-19 pandemic, apart from quality, variant, style and design. In this context, business actors need to take care of CHSE and halal certificates. These certificates will give the impression that the product being offered has met hygiene and halal requirements.

3. In the context of service innovation, this study finds an exciting factor, namely online services. During the Covid19 pandemic, online service innovation was vital because it provided more convenience to consumers who were more often at home. This finding due to various activity restrictions, so that many people carry out activities from home, for example, working from home, studying from home. Online service innovation is an essential factor in service innovation, so it needs to be included as an indicator in research on service innovation overcoming difficulties during a pandemic.

4. Product innovation and service innovation are two interrelated dimensions that cannot be separated from one another, so they must complement each other. Product innovation without service innovation will not have a significant impact on increasing turnover. Conversely, service innovation will not be practical if it is not accompanied by product innovation.

5. Based on these findings, the Innovation as a Determinant Facing the Covid-19 Pandemic model can be described as follows:

Innovation as a Determinant Facing the Covid-19 Pandemic Model

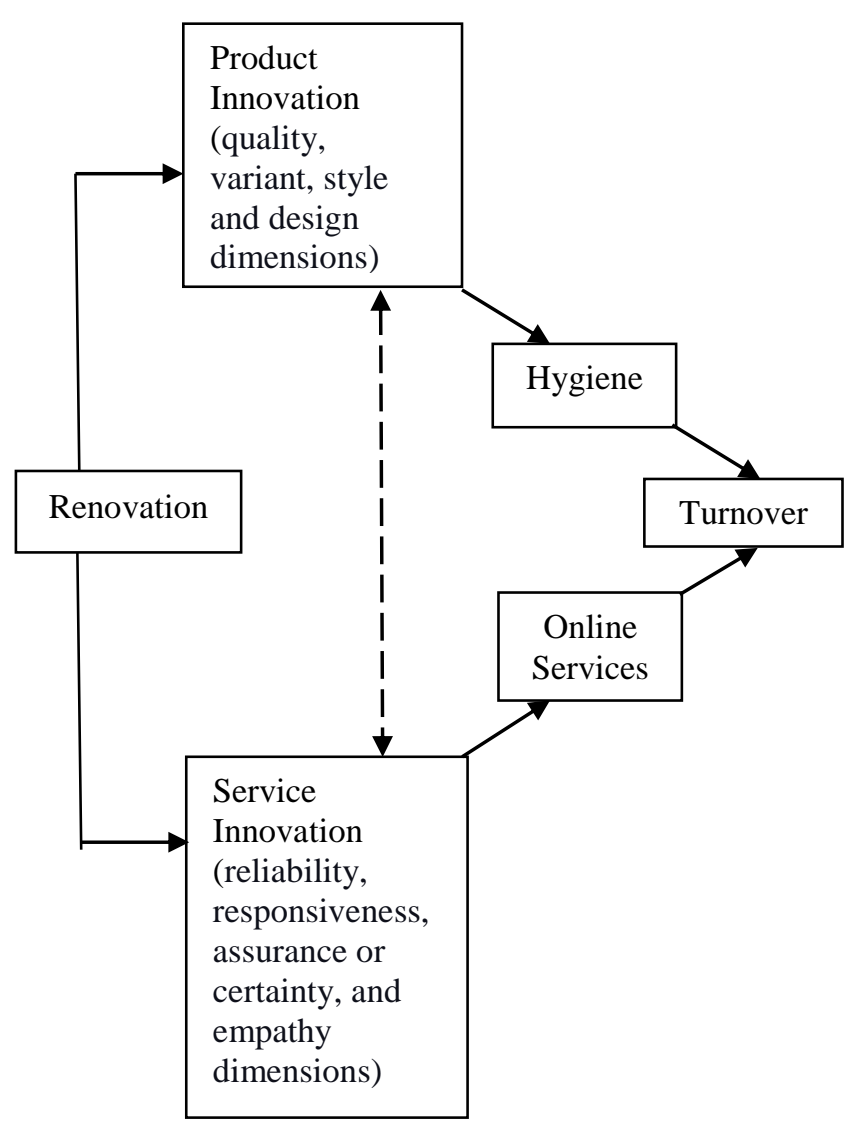

6. For entrepreneurs during the Covid-19 pandemic, renovations, hygiene, and online services are three factors that determine the success of innovation to survive through increased turnover. Renovation is the basis for implementing innovation, while hygiene and online services are factors that influence the success of innovations carried out in order to achieve the expected increase in turnover.

\section{ACKNOWLEDGMENT}

This work was supported by the Faculty of Economics and Business, University of 17 August 1945 (Untag) Semarang.

\section{REFERENCES}

[1] Prahalad, C. K, Managing discontinuities: the emerging challenges, 1998, Research Technology Management

[2] Steel, R. G. D. dan J. H. Torrie, 1989, Principles and procedures of statistics: a biometrical approach, Second edition translation by B. Sumantri, Jakarta, Gramedia Pustaka Utama 
[3] Schumpeter J, 1934, The Theory of Economic Development. An Inquiry into Profits, Capital, Credit, Interest and the Business Cycle. Harvard University

[4] Drucker, P. F, 1994, Innovation and enterpreneurship practise and principles, London: Heinemann

[5] Freeman, C, 1982, The Economics of Industrial Innovation, Cambridge, MA: MIT Press,

[6] Trout, Jack, Steve Rivkin, 2008, Differentiate or Die: Survival in Our Era of Killer Competition, John Wiley \& Sons, Inc, ISBN 978-0-470-223390 (cloth)

[7] Kuznets, S, 1959, Six lectures on economic growth, Chicago: Free Press.

[8] Chesbrough, H. 2003, Open innovation: The new imperative for creating and profiting from technology, Boston: Harvard Business School Press.

[9] Kotler, P, 1976, Marketing, management, Analysis planning and control, Prentice-Hall, Englewood Cliffs. N.J.

[10] Utterback, J. M., \& Abernathy, W, 1975, A dynamic model of process and product innovation, Omega, vol. 3, issue 6, 639-656

https://www.sciencedirect.com/science/article/abs/pii/0305048375900687

[11] Lam, A. 2004, Organizational innovation. Brunel University. Uxbridge. West London. Working Paper, 1. doi: 10.1093/oxfordhb/ 9780199286805.003.0005

[12] Rogers, M, 1998, The definition and measurement of innovation, Melbourne Institute Working Paper, 10/98.

[13] Rothwell, R., C. Freeman, A. Horsley, V. Jervis, A. Robertson and J. Crawford, 1974, "SAPPHO Updated. Project SAPPHO Phase II," Research Policy, 32, 58-291.

[14] Lilien, Gary L, Euansang Yoon, 1988, Characteristics of the Industria Distributor's Innovation Activities - An Exploratory Study, The Journals of Product Innovation Management, vol 5 issue 3, p. 227-240, https://doi.org/10.1111/1540-5885.530227.

[15] Kotler, Amstrong, 2004, Marketing Principals, (translation), Jakarta, Erlangga.

[16] Dougherty, Deborah, 1992, Interpretive Barriers to Successful Product Innovation in Large Firms, Organization Science, Vol. 3, No. 2 (May, 1992), pp. 179-202 Published by: INFORMS

[17] Zeithaml, Valirie A, \& Mary Jo, 2003, Service Marketing Integrating Customer Focus Across The Firm, New York: McGraw-Hill Companies.

[18] Dima Al Eisawi, Harjit Sekhon, and Sailesh Tanna, 2012, Innovation as a Determinant for Service Excellence in Banking International Journal of e-Education, e-Business, e-Management and e-Learning, Vol. 2, No. 4, August 2012

[19] Hanif, Muhammad Imran, Muhammad Umer Asgher, 2018, Service Innovation and Service Innovation Performance: A Study of Banking Services, Pakistan Journal of Commerce and Social Sciences 2018, Vol. 12 (2), 670-694.

[20] Zyman, Sergio, Armin A. Brott, 2004, Renovate before You Innovate, Penguin Group.

[21] Brown, Stephen, 2014, When Innovation Met Renovation: Back to the Future of Branding, Article in Marketing Intelligence \& Planning . August 2015 DOI: 10.1108/MIP-09-2014-0166

[22] Darmanto, 2018, Innovation Orientation and Excellence Compete As Performance Determinant Components: Antecedents Orientation Variable of Entrepreneurship and Learning, International Journal of Economics, Business and Accounting Research (IJEBAR), Vol-2, Issue2, 2018 (IJEBAR) ISSN: 2614-1280, http://www.jurnal.stie-aas/ijebar

[23] Muslichati, Ela Zakiya, Sri Wartini, 2015, The Effect of Service Quality and Service Innovation on Customer Satisfaction in Buah Hati Kudus Hospital, Management Analysis Journal 4 (4) (2015), http://journal.unnes.ac.id/sju/index.php/maj 